\title{
Kajian Mengenai Ekoteologi dari Perspektif Keugaharian
}

\author{
The Study of Ecotheology from Frugality Perspective
}

\author{
Yornan Masinambow ${ }^{1}$, Yuansari Octaviana Kansil ${ }^{2}$ \\ ${ }^{1,2}$ Institut Agama Kristen Negeri Manado \\ yornanmasinambow@gmail.com, ${ }^{2}$ Kansilyuansari@gmail.com
}

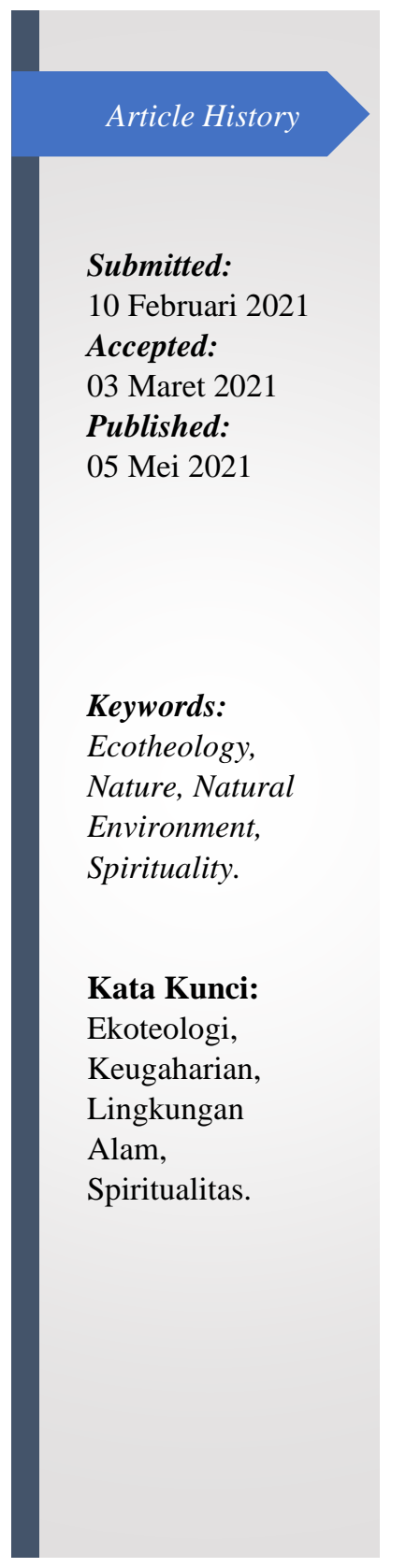

\section{Abstract}

This article aims to explain and reflect an ecological understanding of the natural environment from a theological perspective of frugality. The existence of the thought that humans as the center that result in exploitative actions against nature, treat nature, the environment as objects make environmental damage everywhere. The paradigm of humans who are masters also destroys the relationship between humans and nature itself. Therefore, human consciousness, which began to appear to be struggling with this, presented an ecotheological reflection of the spiritual dimension of spirituality. That way, harmony, loving nature can be formed, applied to human thinking. This study uses a qualitative method with a literature approach to describe the ecotheological views of beauty from various kinds of literature. The results of this study concluded that there were various kinds of views ranging from spirituality, philosophy, and reflection. All of them aim at bringing justice, love, and a sufficient life to be able to build a human attitude for nature and the environment. The eco-theology of passion is also presented by the church in the form of preaching the Word, education, and pastoral care so that the congregation is given a good understanding of the importance of caring for nature which is also God's beautiful creation.

\begin{abstract}
Abstrak
Artikel ini bertujuan untuk menjelaskan serta merefleksikan suatu pemahaman ekoteologi mengenai lingkungan serta alam dari perspektif keugaharian. Adanya pemikiran bahwa manusia sebagai pusat yang mengakibatkan tindakan eksploitatif terhadap alam, memperlakukan alam, lingkungan sebagai objek membuat kerusakan lingkungan dimana-mana. Paradigma manusia yang adalah tuan juga merusak tatanan relasi manusia dengan alam itu sendiri. Oleh karena itu, kesadaran manusia yang mulai nampak menggumuli hal tersebut menghadirkan suatu refleksi ekoteologis dari dimensi spirtualitas keugaharian. Dengan begitu, keselarasan mengasihi alam dapat dibentuk serta diterapkan dalam pola berpikir manusia. Penelitian ini menggunakan metode kualitatif dengan pendekatan kepustakaan untuk mendeskripsikan pandangan-pandangan ekoteologis keugaharian dari berbagai macam literatur. Hasil dari penelitian ini menyimpulkan bahwa ada berbagai macam pandangan mulai dari spiritualitas, filosofis, serta reflektif. Semuanya mengarahkan pada menghadirkan keadilan, cinta kasih, serta kecukupan hidup agar dapat membangun suatu sikap kemanusiaan bagi alam, lingkungan. Ekoteologis keugaharian juga dihadirkan oleh gereja dalam bentuk pemberitaan Firman, Pendidikan, dan pelayanan pastoral agar jemaat diberikan pemahaman yang baik mengenai pentingnya merawat alam yang juga adalah ciptaan Tuhan yang indah.
\end{abstract}




\section{Pendahuluan}

Tidak bisa dipungkiri bahwa krisis ekologis telah terjadi akibat adanya presuposisi atau dasar berpikir bahwa manusia adalah pusat segala sesuatu yang menjadi dasar kehidupan di bumi ini. Maksudnya adalah dengan paham antroposentrisme yang menekankan manusia sebagai pusat alam semesta. Ngahu menjabarkan bahwa konsep berpikir seperti ini cenderung pragmatis, menganggap segala sesuatu mendatangkan profit secara ekonomi yang mau tidak mau membuat alam, lingkungan sekitar harus dieksploitasi serta dapat memberikan kontribusi untuk terus merusak alam dan tidak mempertanggungjawabkannya kepada Tuhan Sang Pencipta alam. ${ }^{1}$ Hal tersebut misalnya berakibat pada rusaknya hutan. Pada awal abad dua puluh misalnya, luas area hutan dapat mencapai lima miliar hektar. Akan tetapi, deforestasi yang terjadi mengakibatkan perkiraan laju kerusakan hutan dapat mencapai tujuh juta hektar per tahun. ${ }^{2}$ Secara kritis, Nainggolan menggambarkan bahwa relasi antara manusia dengan alam dimana mereka hidup hanya dilihat dari perspektif subjek versus objek. Dalam bahasa teologisnya berarti manusia sudah tidak lagi mementingkan makna tentang mandat yang Allah percayakan untuk mengusahakan secara bertanggungjawab serta memelihara lingkungan hidup. Selain itu, perkembangan pemikiran bahwa manusia harus survive, tidak peduli meskipun harus menindas atau merusak alam telah menjadi suatu kultur baru didalamnya. ${ }^{3}$ Penekanan terhadap antroposentrisme yang sudah tertanam dalam pikiran manusia mengakibatkan adanya pandangan dualisme yang memisahkan relasi dimensi Teosentris dengan antroposentris yang terlalu ditekankan kemudian bersifat subordinat, dominatif serta condong eksklusif. Hal-hal inilah yang menjadi dasar akar permasalahan ekologis. ${ }^{4}$.

Oleh karena pola berpikir serta tindakan seperti itulah yang mengakibatkan terjadinya ketidakstabilan lingkungan dimana manusia sendiri itu hidup. Motivasi yang pada awalnya hanya untuk memenuhi kebutuhan dasar hidup manusia pada akhirnya berkembang dengan motivasi pada dominasi oleh gaya dan pola hidup yang berorientasi pada pemenuhan nafsu keserakahan. Menanggapi hal tersebut, maka perlu ditekankan secara teologis apa yang disebut dengan mandat budaya, selain mandat Injil. Jikalau mandat Injil melihat pentingnya warta keselamatan bagi orang-orang yang terhilang oleh karena dosa, dan oleh karenanya membutuhkan kabar keselamatan dalam Yesus Kristus untuk membawa mereka dari kegelapan kepada terang, maka mandat budaya memfokuskan pada manusia menghayati serta melaksanakan tanggung jawab sosial untuk menjaga dan memelihara kesejahteraan ciptaan Tuhan (Kej.1:28). Hal tersebut juga menjadi penekanan dalam Perjanjian Baru (Mat.22:39) untuk mengasihi sesama seperti mengasihi diri sendiri. Berbuat baik kepada orang lain, tidak hanya pada sesama kelompok atau komunitas saja tetapi semua orang, semua ciptaan merupakan kewajiban yang sesuai dengan apa yang dinyatakan dalam Alkitab

\footnotetext{
${ }^{1}$ Silva S Thesalonika Ngahu, "Mendamaikan Manusia Dengan Alam : Kajian Ekoteologi Kejadian1 : 26-28," Pengarah: Jurnal Teologi Kristen 2, no. 2 (2020): 77-88.

${ }^{2}$ Sonny Keraf, Krisis Dan Bencana Lingkungan Hidup Global (Yogyakarta: Kanisius, 2010). 28

3 Herman Nainggolan, Kerusakan Lingkungan, Peran Dan Tanggung Jawab Gereja (Jakarta: Kementerian RI, PGI \& United Evangelical Mission, 2011). 2

${ }^{4}$ Yosef Irianto Segu, "Cinta Ekologis Dalam Pendekatan Estetika Teologis Kristiani," Melintas 32, no. 2 (2016): 214-234.
} 
karena hal tersebut merupakan mandat budaya yang Tuhan percayakan. ${ }^{5}$ Dengan demikian, manusia yang seharusnya bertanggungjawab secara etis-moril untuk merawat, menjaga serta memelihara bumi, lingkungan, alam yang adalah ciptaan Tuhan dan juga rumah bagi ciptaanNya menjadi kabur. Hal inilah yang menjadi suatu disorientasi ekologis juga cerminan terkait persoalan-persoalan yang terjadi dihadapan manusia. ${ }^{6}$ Tetapi perlu juga menjadi perhatian bersama oleh karena dampak dari kerusakan ekologis, timbullah kesadaran secara perlahanlahan bahwa perkara ini bukan hanya manusia dengan alam melainkan Yang Ilahi dengan sesama manusia. ${ }^{7}$

Dari pemaparan di atas, maka kami ingin menawarkan suatu paradigma yang dapat menolong pola berpikir kita manusia sebagai ciptaan-Nya untuk tersadarkan serta bertanggungjawab kepada sesama ciptaan. Istilah yang dipakai terkait hal itu adalah keugaharian. Istilah ini kemungkinan masih tidak terlalu akrab di telinga kita. Keugaharian adalah salah satu perkembangan pemikiran teologis edukatif tentang alam atau lingkungan yang dipikirkan, direfleksikan, digumuli oleh para teolog untuk menghindari sikap 'otoritatif' manusia atas alam. Istilah spiritualitas keugaharian adalah cara menghayati dan menjalani kehidupan agar manusia dan alam atau lingkungan dapat selaras dan bisa terus direstorasi atau diperbaiki. Dalam artikel ini kami mengkaji serta merefleksikan ekoteologi dalam perspektif keugaharian yang tentu saja sangat relevan dalam kehidupan kita sebagai umat Tuhan baik secara komunal maupun personal terhadap alam.

\section{Metode Penelitian}

Dalam tulisan ini, kami menggunakan metode penelitian kualitatif. Menurut Strauss dan Corbin, sebagaimana dikutip oleh Salim dan Syahrum, penelitian kualitatif adalah suatu jenis penelitian yang prosedur penemuannya tidak menggunakan prosedur statistik atau kuantifikasi. Penelitian kualitatif berfokus meneliti tentang kehidupan sosial, perilaku, fungsi organisasi maupun gerakan sosial juga fenomena yang terjadi. ${ }^{8}$ Adapun pendekatan yang digunakan ialah melakukan pendekatan studi literatur. Studi literatur merupakan penelitian yang dilakukan peneliti melalui berbagai macam kajian pustaka, baik buku-buku, jurnal atau dokumen-dokumen yang tertulis, jadi tidak harus turun ke lapangan dan bertemu informan atau responden. Studi literatur membutuhkan ketelitian, ketekunan yang tinggi sehingga data dan beserta analisa kesimpulannya nanti sesuai dengan hasil atau tujuan dari suatu penelitian. ${ }^{9}$ Berdasarkan deskripsi tentang pendekatan penelitian yang digunakan maka sumber data penelitian berasal dari studi literatur berupa buku-buku serta jurnal-jurnal yang membahas tentang ekoteologi juga keugaharian. Bahan-bahan tersebut kemudian

\footnotetext{
${ }^{5}$ Fransiskus Irwan Widjaja, Misiologi: Antara Teori, Fakta Dan Pengalaman (Yogyakarta: ANDI, 2018). 151

${ }^{6}$ Marianus Patora, "Peranan Kekristenan Dalam Menghadapi Masalah Ekologi," Jurnal Teruna Bhakti 1, no. 2 (2019): 117-127.

${ }^{7}$ Segu, "Cinta Ekologis Dalam Pendekatan Estetika Teologis Kristiani.", 220

8 Syahrum Salim, Metodologi Penelitian Kualitatif: Konsep Dan Aplikasi Dalam Ilmu Sosial, Keagamaan Dan Pendidikan (Bandung: Media Citapustaka, 2012). 41

${ }^{9}$ Melfianora, "Penulisan Karya Tulis Ilmiah Dengan Studi Literatur," Open Science Framework (2019): 1-3.
} 
dideskripsikan kemudian dianalisis dan pada akhirnya merumuskan suatu pokok pemikiran secara teologis berkaitan dengan relevansinya bagi kehidupan lingkungan secara ekologis tempat dimana kita berada.

\section{Hasil dan Pembahasan \\ Definisi Konseptual Ekoteologi}

Secara historis, Haeckl yang adalah murid Darwin mencetuskan istilah ekologi. Ia menambahkan istilah itu merujuk kepada keseluruhan organisme atau bisa juga dikatakan pola organisme dan lingkungannya. Merujuk pada etimologi kata, istilah ekologi dari kata Yunani, oikos dan logos. Secara harafiah berarti rumah dan pengetahuan. Dalam ranah ilmu, ekologi berarti pengetahuan tentang lingkungan hidup atau bumi ini secara keseluruhan. ${ }^{10}$ Pemaknaan ekoteologi secara harafiah merupakan gabungan dari kata ekologi dan teologi yang dimana ekoteologi secara khusus memperhatikan kemudian merefleksikan secara teologis kondisi lingkungan dunia sebagai ciptaan Allah yang sedang terancam hancur akibat ulah manusia di antaranya; eksploitasi sumber daya alam secara belebihan, kemudian global warming, pemakaian nuklir, pemakaian bahan-bahan kimia yang berlebihan dan lain sebagainya. Oleh karena itu, ekoteologi berusaha memberikan pengaruh secara positif atas sikap manusia terhadap lingkungannya atau etika lingkungan itu sendiri. ${ }^{11}$ Jadi dapat dikatakan bahwa ekoteologi mencoba menyelesaikan masalah krisis lingkungan dengan menggunakan landasan alkitabiah bahwa lingkungan juga adalah ciptaan Allah. Hal tersebut merupakan bagian dari amanat misi (mission mandate) secara holistik, dimana Tuhan ingin memulihkan pemikiran manusia agar bertindak secara adil terhadap alam melalui pengelolaan yang baik atas tiga sumber daya alam yakni daratan, lautan, dan udara. ${ }^{12}$ Ekoteologi juga merupakan bagian dari teologi konstruktif yang memusatkan perhatian pada hubungan erat antara agama dan alam. Ekoteologi lahir sebagai respons agama-agama, termasuk agama Kristen, terhadap permasalahan-permasalahan dan krisis lingkungan hidup yang terjadi. ${ }^{13}$ Namun seiring dengan meningkatnya permasalahan lingkungan hidup terutama dampak yang ditimbulkannya dalam bentuk berbagai bencana yang terus menerus terjadi diseluruh permukaan bumi ini membuat ekoteologi dari perspektif Kristen berkembang dengan sangat pesat. Gereja dituntut untuk ikut bertanggung jawab mencari jalan keluar menghadapi krisis lingkungan hidup yang sudah sangat parah serta laju kerusakan lingkungan hidup yang terus menerus terjadi dewasa ini. ${ }^{14}$

Penekanan dari ekoteologi adalah bahwa Tuhan tidak hanya berpihak terhadap manusia saja tetapi kepada seluruh ciptaan-Nya. McFague dalam Ngahu juga menjelaskan bahwa hal-hal yang memicu adanya perilaku eksploitatif terhadap lingkungan sekitar atau alam adalah adanya pandangan yang merujuk pada model monarkis - Allah jauh dari dunia.

\footnotetext{
${ }^{10}$ Robert P. Borrong, Etika Bumi Baru (Jakarta: BPK Gunung Mulia, 2003). 18

${ }^{11}$ Celia Deane-Drummond, Teologi Dan Ekologi: Buku Pegangan (Jakarta: BPK Gunung Mulia, 2006).

12 Sabar Manahan Hutagalung, Fransiskus Irwan Widjaja, and Daniel Ginting, "Teologi Misi Sebagai Teologi Amanat Agung,” THRONOS: Jurnal Teologi Kristen 1, no. 1 (2019): 17-24.

${ }^{13}$ Deane-Drummond, Teologi Dan Ekologi: Buku Pegangan. 148

${ }^{14}$ Ibid. 150
} 
Dari perspektif ekotelogi, seluruh alam semesta semestinya dipahami sebagai tubuh Tuhan. Tuhan juga diproyeksikan sebagai ibu yang punya sifat penuh kasih, cinta serta bersahabat. Dengan demikian, jikalau hal tersebut dimaknai oleh manusia, maka manusia sendiripun akan mempunyai kesadaran, posisi bukan untuk memanipulasi, memerintah, mengusai melainkan untuk bersahabat, juga mengasihi sesama ciptaan. ${ }^{15}$

\section{Ekoteologi Keugaharian: Perspektif Spiritualitas}

Keugaharian adalah kebijaksanaan hidup bahwa rahmat Tuhan cukup untuk semua ciptaan-Nya. Karena itu manusia didorong mengendalikan diri dan hidup sederhana dalam sikap kecukupan dan bersedia berbagi dengan sesama agar semua ikut merayakan kehidupan yang diberikan. ${ }^{16}$ Yewangoe menjelaskan bahwa keugaharian berarti kesederhanaan, kesahajaan dimana walaupun harta yang bersangkutan melimpah ruah, ia tetap hidup dalam "ugahari” dan sangat dicintai oleh rakyatnya. Oleh karena itu "ugahari” merupakan kesiapan untuk hidup sederhana, merasa ada dengan yang ada, tidak serakah dengan yang ada (kendati berlimpah-ruah). Ini juga menyiratkan bahwa seseorang yang hidup dalam ke-ugahari-an tidak harus bertarak (asketis) dalam kehidupan. Ia tidak perlu munafik dengan kehidupan ini. ${ }^{17}$ Hidup dalam kesederhanaan juga berkecukupan merupakan semangat dari spiritualitas keugaharian. Dapat juga dikatakan bawa keugaharian adalah mentalitas atas hidup serta melihat kehidupan sebagai sebuah hal yang harus dihargai dan merupakan suatu anugerah dari Tuhan. Hidup secara ugahari tidak berarti memiskinkan diri, tetapi untuk hidup bersyukur. ${ }^{18}$ Spiritualitas keugaharian adalah cara menghayati dan menjalani kehidupan yang berdasarkan pada etos hidup yang berkecukupan. Hidup berkecukupan merupakan gaya hidup yang perlu dikembangkan oleh orang-orang percaya atau warga gereja. Hidup berkecukupan dapat dikatakan sebagai hidup yang berlandaskan Alkitab. ${ }^{19}$ Yesus Kristus menjalani kehidupan yang sangat ugahari, sehingga bahkan bantalpun Ia tidak punya untuk meletakkan kepala-Nya (lihat Matius 8:20; Lukas 9:58).

Spiritualitas yang Ugahari dapat menjadi model dalam hal pengembangan kualitas kehidupan serta pelayanan dalam hal ini masyarakat juga gereja dengan terus menjaga serta memelihara sikap untuk mengasihi juga menolong sesama tanpa harus melihat latar belakang sosial, budaya agama atau perbedaan identitas sosial, terutama bagi mereka yang lemah, dimarginalkan, tertindas baik manusia ataupun alam. Tema tentang keugaharian diangkat dalam sidang MPL-PGI 2015 di Malinau dan Sidang MPL-PGI 2016 di Parapat, serta samasama mengangkat "Spiritualitas Keugaharian" sebagai bahan diskusi. Di Malinau, pokok diskusi yang diangkat adalah pada aspek perilaku hidup keseharian warga gereja, sedangkan

\footnotetext{
${ }^{15}$ Ngahu, "Mendamaikan Manusia Dengan Alam : Kajian Ekoteologi Kejadian1 : 26-28."

16 Suryati Simanjuntak Albertus Patty, "Keugaharian: Cukup Dan Berbagai Untuk Keberlanjutan Kehidupan," MPK-PGI2.

17 Andreas. A. Yewangoe, "Spiritualitas Keugaharian: Merayakan Keragaman Bagi Kehidupan Kebangsaan Yang Utuh - Website PGI."

${ }^{18}$ Nurelni Limbong, "SPRITUALITAS KEUGAHARIAN (Studi Injil Lukas 3:10-14),” Jurnal Teologi Cultivation 4, no. 1 (2020): 104-114.

${ }^{19}$ Claartje Pattinama, "Spiritualitas Keugaharian: Perspektif Pastoral," Panel Diskusi HUT Pendidikan Teologi ke-132 (2018): 1-4.
} 
di Parapat, penekanan diskusi yakni pada aspek lingkungan hidup, kebhinekaan dan solidaritas sosial. Menjadi suatu realitas bersama bahwa masyarakat Indonesia hidup dalam kemajemukan dengan berbagai latar belakang yang berbeda antara satu dengan yang lainnya. Keragaman, kemajemukan baik dari budaya, bahasa, bahkan kepercayaan tersebut telah menjadi ciri khas baik keluarga, maupun gereja/denominasi, agama-agama. Dari segi sosiologis, kehidupan masyarakat yang ada di Indonesia menekankan religiusitas serta menerima suatu kultur dengan nilai-nilai spiritual yang ada di dalamnya, khususnya menekankan tanggung jawab berbagai kepercayaan untuk bekerja sama serta bertindak sebagai agen Tuhan dalam hal mempromosikan hidup yang damai dan harmonis. ${ }^{20}$ Oleh karenanya, penerapan akan kesadaran spiritualitas keugaharian menjadi hal yang harus diperhatikan. Namun, dapat dijumpai di berbagai sudut kota, desa dapat ditemukan, atau dilihat adanya kemiskinan, kekurangan gizi, kesenjangan sosial, ketidakadilan, radikalisme serta perusakan lingkungan yang berdampak pemiskinan dan juga bencana alam. Semua ini terjadi lantaran kerakusan dan ketidakpedulian manusia terhadap sesamanya dan lingkungannya. Banyak orang yang rela mati, merugikan serta mencelakai banyak orang hanya demi melampiaskan fanatisme, kehausan akan kekuasaan yang dianutnya, ketamakan yang terus meluas serta merusak, juga mencemari alam ciptaan Allah yang telah diciptakan dengan amat baik, tanpa pernah berpikir tentang kelangsungan hidup yang akan datang. ${ }^{21}$ Jadi, dari paparan tersebut nyatalah bahwa ekoteologi dari sisi spiritualitas keugaharian merupakan hal penting yang harus ditanamkan, dihayati serta dipraktikkan kepada masyarakat dan juga warga gereja terlebih khusus.

\section{Keugaharian: Perspektif Filosofis}

Pemikiran secara filosofis dapat dikategorikan dalam lima periode berdasarkan corak pemikiran yang dominan. Kelima periode tersebut bisa diurutkan secara bertahap, yaitu: periode naturalis, humanistis, sistematis, etika, dan religius. Seperti yang dikenakan padanya, periode naturalistis menekankan perhatian pada asal-usul dan prinsip-prinsip dasar yang membentuk alam semesta. Disini manusia mulai mempertanyakan segala sesuatu dan mencoba mendapatkan jawabannya dengan kekuatan akalnya melalui prinsip-prinsip metodologis dan tidak lagi menerima begitu saja secara pasif berbagai macam mitos-mitos serta penjelasan yang ada secara dogmatis. ${ }^{22}$ Namun, pada tahapan perkembangannya secara humanistis etis-religius, refleksi manusia juga mengantarkannya untuk dapat memahami secara bijak bahwa Tuhan Yang Maha Kuasa juga menciptakan segala sesuatu termasuk alam. Melalui alam semesta sebenarnya kehidupan manusia memiliki makna yang begitu mendalam. Selain itu, melalui interaksi, interrelasi antara manusia dan alam punya fungsi dan peran-peran masing-masing yang saling menopang, menguatkan antara satu dengan yang lain. ${ }^{23}$

\footnotetext{
${ }^{20}$ Fransiskus Irwan Widjaja, "Pluralitas Dan Tantangan Misi : Kerangka Konseptual Untuk Pendidikan Agama," Regula Fidei: Jurnal Pendidikan Agama Kristen 4, no. 1 (2019): 1-13.

${ }^{21}$ Albertus Patty, "Keugaharian: Cukup Dan Berbagai Untuk Keberlanjutan Kehidupan.”, 6

${ }^{22}$ Laurentius Tinambunan, "Filsafat Sebagai Preparatio Evangelica: Selayang Pandang Peranan Filsafat Yunani Pada Awal Pewartaan Kekristenan," Jurnal Forum Biblika Ilmiah Populer (2010): 6.

23 Armaidy Armawi, "Kajian Filosofis Terhadap Pemikiran Human-Ekologi Dalam Pemanfaatan
} 
Sebelumnya dikatakan bahwa ada kecenderungan manusia untuk mau menguasai alam atau mendominasi alam, maka kemungkinan besar bahwa manusia mengarahkan hidup mereka pada usaha-usaha pribadi untuk mencapai kebahagiaan hidup dimana mereka ada. Menarik untuk memperhatikan pandangan filsafat tradisional Yunani kuno yakni stoisisme atau kaum Stoa yang didirikan oleh Zeno. Aliran ini bersifat sungguh materialistis. Dalam pandangan Stoa segala sesuatu bersifat material; tidak ada apa pun yang tidak bersifat materi. Menurut kaum Stoa, alam semesta bukanlah sesuatu yang tanpa arti, yang tidak mempunyai tatanan. Bagi mereka tidak ada yang kebetulan, sebaliknya semuanya serba teratur dan tersusun rapi menurut hukum-hukum yang tetap dan pasti. Alam semesta dilukiskan sebagai seekor binatang raksasa yang mempunyai badan (materi) dan jiwa (api). ${ }^{24}$ Corak berpikir materialistis yang ada dalam pemikiran manusia tidak lagi segan-segan untuk melakukan berbagai tindakan eksploitasi alam dan isinya secara besar-besaran, demi kepentingan dan hidup manusia tanpa memikirkan akibat dari perbuatan yang dilakukan terhadap alam. ${ }^{25}$

Dari aspek filosofis yang dapat dipertimbangkan terkait ekoteologi keugaharian ialah pemikiran kontemporer teologi proses yang berakar dari pemikiran filososfis Alfred North Whitehead dan Charles Harthshorne. Borrong menjelaskan bahwa mereka melihat bahwa ciptaan dalam hal ini alam merupakan suatu proses yang sifatnya dinamis, berkelanjutan, tidak produk akhir. Mereka juga tidak menekankan bahwa Tuhan adalah Tuhan penguasa mutlak (all powerful) melainkan Tuhan dipandang sebagai Tuhan pengasih mutlak (allloving). Implikasinya tidak ada kehidupan yang dilihat sebagai obyek melainkan seluruh ciptaan harus dipandang sebagai subyek. Oleh karena itulah mengapa seluruh kehidupan termasuk alam lingkungan harus dihargai dikarenakan semuanya punya nilai intrinsik bersama. ${ }^{26}$ Pandangan lain juga datang dari Harvey Cox dalam tulisannya Secular City, sebagaimana dijabarkan Martin Harun bahwa secara teologis-filosofis oleh karena perkembangan interpretasi tentang kisah penciptaan dalam Alkitab membuat suatu paradigma yakni memisahkan alam dari Allah dan membedakan manusia dari alam. Dengan demikian, alam dilepaskan dari persona ilahinya dan dapat dilihat sebagai objek biasa. Akan berbeda jikalau diadakannya suatu perbandingan dengan paham-paham atau kepercayaan lain misalnya pemahaman mitologi Yunani kuno atau agama non-monoteistis yang memandang bahwa Sang Ilahi sebagai imanen di dalam dunia, dan karena itu bumi adalah sakral bagi mereka sehingga tidak begitu bebas dapat digunakan atau dieksploitasi secara sembarangan oleh manusia. Jadi, penekanan secara berlebihan pada ketransendenan Tuhanlah yang juga menjadi faktor pelemahan atau ketidakpekaan manusia akan sisi sakral alam dan membuka jalan bagi penyalahgunaannya. Alam dilepaskan dari sisi keilahiannya dan menjadi bahan sekular. ${ }^{27}$ Analisa-analisa secara filosofis-teologis tersebut dapat

Sumber Daya Alam,” Jurnal Manusia dan Lingkungan 20, no. 1 (2013): 57-67.

${ }^{24}$ Tinambunan, "Filsafat Sebagai Preparatio Evangelica: Selayang Pandang Peranan Filsafat Yunani Pada Awal Pewartaan Kekristenan." 9

${ }^{25}$ Hardiansyah, "Filsafat Menjadi Alternatif Pencegah Kerusakan Lingkungan," Jurnal Substantia 14, no. 2 (2012): 243-250.

${ }^{26}$ Robert P. Borrong, "Kronik Ekoteologi: Berteologi Dalam Konteks Krisis Lingkungan,” Jurnal Stulos 17, no. 2 (2019): 185-212.

${ }^{27}$ Martin Harun, “Allah Para Ekoteolog,” in Dunia, Manusia, Dan Tuhan: Antologi Pencerahan Filsafat Dan Teologi (Pesta 80 Tahun P. Louis Leahly, SJ), ed. J. Sudarminta \& S.P. Lili Tjahjadi (Yogyakarta: 
menyadarkan kita bahwa pentingnya keugaharian sebagai bagian dari sikap, pandangan dan, tingkah laku (behaviuor), nilai (value), serta kepercayaan (belief) yang ada dalam diri manusia untuk terus dihayati dengan baik. Hal tersebut dapat membentuk suatu worldview bahwa alam, lingkungan sekitar merupakan bagian dari hidup manusia yang harus dijaga sekalipun secara perlahan-lahan.

\section{Ekoteologi Keugaharian: Deep-Ecology}

Deep-Ecology merupakan paham yang menyatakan bahwa di dalam segala sesuatu (juga termasuk yang tampak "mati" sekalipun) ada kehidupan, ada dinamika, ada proses, ada gerak. Paham deep-ecology ini diajukan para ahli sebagai upaya perbaikan pada tingkat wacana dan pemikiran untuk pelbagai akibat negatif karena krisis serta bencana ekologi (seperti efek rumah kaca, bolongnya lapisan ozon, pencemaran air dan udara, deforestrasi, eksploitasi alam, pelbagai efek limbah). Paham ini diajukan bersama dengan gerakan ekoteologi, ekospiritualitas, dan juga ekofeminisme. ${ }^{28}$ Misalnya, pandangan ekofeminis yang menekankan secara khusus pada pada kehancuran alam yang diyakini berkaitan erat dengan isu gender. Singkatnya, ekofeminisme mempersalahkan kaum laki-laki atas krisis ekologis. ${ }^{29}$ Deep-ecology menunjukkan bahwa adanya nilai pada alam yang mendorong manusia untuk dapat memiliki kewajiban moral untuk terus mau menghormatinya. ${ }^{30}$ Deepecology keugaharian mendorong paradigma baru bahwa alam di sekitar kita cukup untuk memenuhi kebutuhan (need) semua orang, serta menyingkirkan paradigma lama bahwa alam dapat memuaskan nafsu keserakahan ( greed) setiap orang. Dengan paradigma baru tersebut, manusia dapat kembali kepada kebajikan dasar yakni pengendalian diri, atau hidup sederhana, yang sangat penting bagi kehidupan manusia baik dari sisi ekologis maupun ekonomis. Selain itu, deep ecology mendorong manusia untuk memelihara lingkungan alam. Deep-ecology Ekosentrisme menjadi sebuah pedoman bagi manusia dalam memperlakukan alam dan lingkungan hidup. Deep-ecology Ekosentrisme menawarkan kesadaran ekologis bagi manusia, yaitu kesadaran untuk mampu melihat dirinya sebagai bagian dari alam. Kesadaran ekosentris tersebut merupakan langkah awal untuk menciptakan ekosistem yang harmoni dan sehat. ${ }^{31}$

\section{Refleksi Teologis Keugaharian}

Gereja diutus ke dalam dunia untuk bersaksi tentang kehendak Tuhan dalam realitas kehidupan mereka, dan Gereja ditugaskan untuk menjaga dan melindungi kehidupan manusia agar dapat mengalami hidup yang berkecukupan sebagaimana yang terungkap dalam penggalan doa Bapa Kami (Mat. 6:11). “Gereja sahabat alam” yang dirumuskan oleh

Kanisius, 2008), 30-31.

${ }^{28}$ Fransiskus Borgias, "Dari 'Deep Ecology' Ke 'Deep Economy' - SHNet.”

${ }^{29}$ Deane-Drummond, Teologi Dan Ekologi: Buku Pegangan. 62

${ }^{30}$ Ivanovich Agusta, "Kritik Ekologi Poskolonial : Dari Kontrol Pembangunan Yang Berkelanjutan Menuju Praksis Ekologi Bersama," Jurnal Transdisiplin Sosiologi, Komunikasi, dan Ekologi Manusia 03, no. 01 (2009).

${ }^{31}$ Muhammad Yusuf, "Stresor Manusia Sebagai Dampak Krisis Atmosfer Global Dalam Kajian Deep Ecology Ekosentrisme” (2018). 
Sidang Majelis Pekerja Lengkap PGI di Kupang menjadi sebuah bahan refleksi bagi gerejagereja di Indonesia untuk menjadi sahabat yang ramah kepada alam. ${ }^{32}$ Pandangan ini dapat menjadi suatu tugas missional yang dilaksanakan dalam bentuk pemberitaan firman, pelayanan pastoral dan juga pendidikan bergereja. Oleh karenanya, setiap bentuk-bentuk pelaksanaan tersebut direfleksikan berdasarkan nilai-nilai iman kristiani yang juga menekankan kemanusiaan serta kasih Allah dalam Yesus Kristus. ${ }^{33}$ Perlu diperhatikan bahwa menjalankan panggilan Tuhan melalui misi gereja di bumi bukan saja memperhatikan keselamatan manusia, namun juga menaruh perhatian terkait hal-hal ekoteologis. ${ }^{34}$

Dalam hubungan itu, Gereja sebagai persekutuan orang percaya perlu mengembangkan spiritualitas teologis keugaharian. Dalam hal ini jemaat perlu menghayati serta mempraktekkan pola hidup yang berkecukupan. Jika ada anggota jemaat yang berkelebihan atau berkelimpahan ada baiknya ia dilayani agar dapat mempraktekkan dan mengembangkan gaya hidup berbagi dengan anggota lain dalam persekutuan maupun orang di luar persekutuan. Dengan demikian kelebihan atau kelimpahannya mencukupkan kebutuhan orang lain. ${ }^{35}$ Tidak dapat dipungkiri sekarang bahwa pola konsumerisme, hedonist serta sifat individualisme ada serta dilakukan dalam kehidupan manusia. Namun, dengan terus secara dinamis menanamkan dalam setiap pikiran dan hati kita secara teologis bahwa kita sebagai ciptaan Tuhan seyogyanya tidak hanya mementingkan diri kita sendiri tetapi juga peduli dan mengasihi sesama kita, termasuk alam. ${ }^{36}$ Refleksi teologis yang juga perlu menjadi perenungan dan menjadi praksis kehidupan kita sebagai orang percaya adalah dalam tulisan Paulus dalam Filipi 4:11 yang menyatakan: "sebab aku telah belajar mencukupkan diri dalam segala keadaan". Nas ini hendak menunjukkan bahwa sebagai sebagai orang percaya, kita harus memahami benar gaya hidup yang harus dipraktekkan dan perlihatkan kepada sesama khususnya warga jemaat, bahwa dalam berpelayanan tidak menuntut atau menekan sesama ciptaan untuk memenuhi kebutuhan hidupnya secara berkelebihan

\section{Kesimpulan}

Secara teologis, pandangan mengenai keugaharian merupakan sintesis terhadap masalah lingkungan dari perspektif ekoteologi. Semua tradisi Kristen punya potensi untuk menemukan serta mengungkapkan perhatian terhadap lingkungan. Keugaharian bersifat ekumenis serta misional yang berarti bahwa segala denominasi gereja harus memberi perhatian yang sangat dalam khususnya persoalan lingkungan. Ekoteologi yang ugahari berdasarkan nilai-nilai spritualitas teologis biblis dapat mengarahkan manusia untuk hidup

32 Andreas. A. Yewangoe, Hidup Dari Pengharapan: Mempertanggungjawabkan Pengharapan Di Tengah Masyarakat Majemuk Indonesia (Jakarta: BPK Gunung Mulia, 2017). 216

${ }^{33}$ Ngahu, "Mendamaikan Manusia Dengan Alam : Kajian Ekoteologi Kejadian1 : 26-28."

34 Jefri Hina Remikatu, "Teologi Ekologi: Suatu Isu Etika Menuju Eskatologi Kristen," CARAKA: Jurnal Teologi Biblika dan Praktika 1, no. 1 (2020): 65-85.

${ }^{35}$ Pattinama, "Spiritualitas Keugaharian: Perspektif Pastoral."

36 Radot S. Simanjuntak, "KEUGAHARIAN DAN KONSUMERISME: Suatu Tinjauan Deskriptif Analitis Atas Pandangan John Wesley Tentang Keugaharian Dan Relevansinya Dengan Budaya Konsumerisme" (Universitas Kristen Duta Wacana, 2017). 
berkecukupan, bertanggungjawab, menghadirkan kepedulian, cinta kasih, bersahabat bagi alam. Pandangan tersebut mampu untuk menekan pola pikir yang hedonis, konsumeris, ingin menguasai secara berlebihan terhadap sesama ciptaan agar hal-hal buruk tidak menimpa lingkungan alam dan juga kehidupan manusia. Dalam praksisnya, sifat missional gereja juga harus menekankan semangat ekologis yang ugahari dalam bentuk pemberitaan firman, pendidikan atau ajaran di gereja serta pelayanan pastoral kepada jemaat. Gereja yang didalamnya terdapat pendeta, majelis harus menjadi patron atau teladan dalam memberikan landasan edukatif teologis kepada warga gereja bahkan masyarakat tentang pentingnya kecukupan hidup, untuk tidak menjadi serakah, dan menyayangi alam, lingkungan sama seperti kasih Kristus kepada umat manusia.

\section{Daftar Pustaka}

Agusta, Ivanovich. "Kritik Ekologi Poskolonial: Dari Kontrol Pembangunan Yang Berkelanjutan Menuju Praksis Ekologi Bersama." Jurnal Transdisiplin Sosiologi, Komunikasi, dan Ekologi Manusia 03, no. 01 (2009).

Albertus Patty, Suryati Simanjuntak. "Keugaharian: Cukup Dan Berbagai Untuk Keberlanjutan Kehidupan." MPK-PGI2.

Armawi, Armaidy. "Kajian Filosofis Terhadap Pemikiran Human-Ekologi Dalam Pemanfaatan Sumber Daya Alam.” Jurnal Manusia dan Lingkungan 20, no. 1 (2013): 57-67.

Borgias, Fransiskus. "Dari 'Deep Ecology' Ke 'Deep Economy' - SHNet.”

Borrong, Robert P. Etika Bumi Baru. Jakarta: BPK Gunung Mulia, 2003. . "Kronik Ekoteologi: Berteologi Dalam Konteks Krisis Lingkungan." Jurnal Stulos 17, no. 2 (2019): 185-212.

Deane-Drummond, Celia. Teologi Dan Ekologi: Buku Pegangan. Jakarta: BPK Gunung Mulia, 2006.

Hardiansyah. "Filsafat Menjadi Alternatif Pencegah Kerusakan Lingkungan." Jurnal Substantia 14, no. 2 (2012): 243-250.

Harun, Martin. "Allah Para Ekoteolog." In Dunia, Manusia, Dan Tuhan: Antologi Pencerahan Filsafat Dan Teologi (Pesta 80 Tahun P. Louis Leahly, SJ), edited by J.

Sudarminta \& S.P. Lili Tjahjadi, 30-31. Yogyakarta: Kanisius, 2008.

Hutagalung, Sabar Manahan, Fransiskus Irwan Widjaja, and Daniel Ginting. "Teologi Misi

Sebagai Teologi Amanat Agung.” THRONOS: Jurnal Teologi Kristen 1, no. 1 (2019): $17-24$.

Keraf, Sonny. Krisis Dan Bencana Lingkungan Hidup Global. Yogyakarta: Kanisius, 2010. Limbong, Nurelni. "SPRITUALITAS KEUGAHARIAN (Studi Injil Lukas 3:10-14)." Jurnal Teologi Cultivation 4, no. 1 (2020): 104-114.

Melfianora. "Penulisan Karya Tulis Ilmiah Dengan Studi Literatur." Open Science Framework (2019): 1-3.

Nainggolan, Herman. Kerusakan Lingkungan, Peran Dan Tanggung Jawab Gereja. Jakarta:

Kementerian RI, PGI \& United Evangelical Mission, 2011.

Ngahu, Silva S Thesalonika. "Mendamaikan Manusia Dengan Alam : Kajian Ekoteologi 
Kejadian1 : 26-28." Pengarah: Jurnal Teologi Kristen 2, no. 2 (2020): 77-88.

Patora, Marianus. "Peranan Kekristenan Dalam Menghadapi Masalah Ekologi." Jurnal Teruna Bhakti 1, no. 2 (2019): 117-127.

Pattinama, Claartje. "Spiritualitas Keugaharian: Perspektif Pastoral." Panel Diskusi HUT Pendidikan Teologi ke-132 (2018): 1-4.

Remikatu, Jefri Hina. "Teologi Ekologi: Suatu Isu Etika Menuju Eskatologi Kristen." CARAKA: Jurnal Teologi Biblika dan Praktika 1, no. 1 (2020): 65-85.

Salim, Syahrum. Metodologi Penelitian Kualitatif: Konsep Dan Aplikasi Dalam Ilmu Sosial, Keagamaan Dan Pendidikan. Bandung: Media Citapustaka, 2012.

Segu, Yosef Irianto. "Cinta Ekologis Dalam Pendekatan Estetika Teologis Kristiani." Melintas 32, no. 2 (2016): 214-234.

Simanjuntak, Radot S. "KEUGAHARIAN DAN KONSUMERISME: Suatu Tinjauan

Deskriptif Analitis Atas Pandangan John Wesley Tentang Keugaharian Dan Relevansinya Dengan Budaya Konsumerisme.” Universitas Kristen Duta Wacana, 2017.

Tinambunan, Laurentius. "Filsafat Sebagai Preparatio Evangelica: Selayang Pandang Peranan Filsafat Yunani Pada Awal Pewartaan Kekristenan.” Jurnal Forum Biblika Ilmiah Populer (2010): 6.

Widjaja, Fransiskus Irwan. Misiologi: Antara Teori, Fakta Dan Pengalaman. Yogyakarta: ANDI, 2018.

. "Pluralitas Dan Tantangan Misi : Kerangka Konseptual Untuk Pendidikan Agama." Regula Fidei: Jurnal Pendidikan Agama Kristen 4, no. 1 (2019): 1-13.

Yewangoe, Andreas. A. Hidup Dari Pengharapan: Mempertanggungjawabkan Pengharapan Di Tengah Masyarakat Majemuk Indonesia. Jakarta: BPK Gunung Mulia, 2017.

_. "Spiritualitas Keugaharian: Merayakan Keragaman Bagi Kehidupan Kebangsaan Yang Utuh - Website PGI."

Yusuf, Muhammad. "Stresor Manusia Sebagai Dampak Krisis Atmosfer Global Dalam Kajian Deep Ecology Ekosentrisme" (2018). 